\title{
PENGEMBANGAN UNIT USAHA USU PELAYANAN LABORATORIUM PATOLOGI ANATOMIK TAHUN 2020
}

\author{
Delyuzar $^{1^{*}}$, Muhammad Ramli ${ }^{2}$, Tengku Ibnu Alferraly ${ }^{1}$, Hidayat ${ }^{3}$, Dedy Suryadi ${ }^{1}$ \\ ${ }^{1}$ Departemen Patologi Anatomik, Fakultas Kedokteran, Universitas Sumatera Utara, Medan, Indonesia \\ ${ }^{2}$ Fakultas Ekonomi, Universitas Sumatera Utara, Medan, Indonesia \\ ${ }^{3}$ Fakultas Kedokteran, Universitas Sumatera Utara, Medan, Indonesia \\ * Penulis Korespodensi : dr_delyuzar@yahoo.com, delyuzar@usu.ac.id
}

\begin{abstract}
Abstrak
Seiring dengan perkembangan zaman dan teknologi di semua bidang, termasuk laboratorium patologi anatomik, maka laboratorium patologi anatomik FK USU juga harus ikut berperan terhadap segala perubahan, terutama dalam hal kepentingan USU, baik dalam hal akreditasi maupun usaha meningkatkan pendapatan melalui unit usaha mandiri. Potensi yang dimiliki unit usaha pelayanan patologi anatomik sangat besar untuk dikembangkan, diantaranya pelayanan patologi anatomik terhadap pasien dan masyarakat, pendidikan dan penelitian terhadap mahasiswa, ini semua harus difasilitasi dan dikembangkan dengan cara dukungan unit usaha berbasis sistem teknologi informasi. Ada beberapa kendala yang dihadapi pada program ini, diantaranya keterbatasan tenaga kesehatan dan peralatan.Pengabdian ini bertujuan untuk meningkatkan kunjungan pasien dan penghasilan laboratorium patologi anatomik FK USU, solusi berupa perbaikan manajemen professional dan promosi laboratorium patologi anatomik yang dapat melakukan pelayanan yang lebih lengkap berbasis biologi molekuler dan teknologi informatika untuk kepentingan akreditasi dan pendapatan dari unit usaha pelayanan patologi anatomik FK USU. Tahun 2021 kita harapkan unit usaha ini telah berkembang sebagi laboratorium patologi anatomik dengan pemeriksaan biologi molekuler dan menjadi pusat konsultasi berbasis web dan teknologi informatika.
\end{abstract}

Kata kunci: Laboratorium, Patologi Anatomik, Web, Teknologi Informatika

\begin{abstract}
Along with the times and technology in all fields, including the anatomic pathology laboratory, the USU Faculty of Medicine anatomical pathology laboratory must also play a role in all changes, especially in terms of USU's interests, both in terms of accreditation and efforts to increase revenue through independent business units. The potential of the anatomic pathology service business unit is very large to be developed, including anatomic pathology services to patients and the community, education and research for students, all of which must be facilitated and developed by means of supporting business units based on information technology systems. It is recognized that there are still obstacles in the implementation of this program, including limited equipment and health personnel. This service aims to increase patient visits and income of the USU FK USU's anatomic pathology laboratory, solutions in the form of improved professional management and promotion of an anatomic pathology laboratory that can provide services more complete based on molecular biology and information technology for the benefit of accreditation and revenue from the anatomic pathology service business unit, FK USU. In 2021, we hope that this business unit will develop into an anatomic pathology laboratory with molecular biology examinations and become a web-based consulting center and information technology.
\end{abstract}

Keywords: Laboratory, Anatomical Pathology, Web, Information Technology 


\section{PENDAHULUAN}

Departemen Patologi Anatomik Fakultas Kedokteran Universitas Sumatera Utara berdiri sejak tahun 1954, dr. Darwis D. Besar menjadi pimpinan pertama kala itu, beliau mempunyai pengalaman menjadi asisten Patologi NIAS di Surabaya pada tahun 1930. Pemeriksaan histopatologi pada awalnya dilakukan di Laboratorium Kesehatan Daerah dipimpin Dr. Med. H. G. P. Kern hingga tahun 1966. Pemeriksaan histopatologi sempat terhenti sekitar dua tahun, dr. Waldemar Tambunan membuka kembali pemeriksaan histopatologi bekerjasama dengan Departemen Patologi Fakultas Kedokteran Universitas Andalas pada tahun 1968-1969.

Departemen Patologi Anatomik terletak di Gedung Abdul Hakim lt. 1 Fakultas Kedokteran USU di Jl. Universitas. Selain memberikan pelayanan kepada masyarakat, departemen Patologi Anatomik juga menjadi pusat pendidikan hingga saat ini.

Patologi anatomik merupakan ilmu yang mempelajari tentang penyakit secara makroskopis dan mikroskopis yang bertujuan untuk menegakkan diagnosis penyakit melalui pemeriksaan sel, jaringan dan organ tubuh manusia. Pada pemeriksaan lebih lanjut, terkadang dibutuhkan pengecatan khusus dan imunohistokimia. Seiring perkembangan teknologi, Patologi anatomik mulai menggunakan biologi molekuler untuk memperoleh informasi tambahan. Terdapat dua jenis pemriksaan yang rutin dilakukan di Departemen Patologi Anatomik yaitu pemeriksaan Histopatologi dan Sitopatologi.

Kunjungan pasien ke laboratorium patologi anatomik FK USU masih minim, ini mungkin disebabkan pelayanan patologi anatomik masih bersifat pasif, menunggu pasien datang. Oleh karena itu promosi dan pengembangan laboratorium patologi anatomik perlu dilakukan secara aktif. Disamping perlu peningkatan kesadaran masyarakat dan pengetahuan tentang patologi anatomik. Dibutuhkan juga dukungan dari stake holder untuk mendukung program pemberdayaan masyarakat. Untuk itu dibutuhkan peran serta masyarakat yang lebih terprogram dan terukur, agar pelayanan patologi anatomik di tengah-tengah masyarakat akan dapat lebih berjalan dengan baik.

\section{METODE}

Menurut catatan yang didapatkan berdasarkan data di laboratorium patologi anatomik Fakultas Kedokteran USU rata-rata kunjungan pasien 30 orang per bulan. Angka ini sangat sedikit bila melihat potensi laboratorium patologi anatomik yang sangat mungkin untuk dikembangkan. Rendahnya kunjungan pasien dan penghasilan laboratorium patologi anatomik FK USU, solusi berupa perbaikan manajemen professional dan promosi laboratorium patologi anatomik yang dapat melakukan pelayanan yang lebih lengkap berbasis biologi molekuler dan teknologi informatika.

Pemilihan laboratorium patologi anatomik FK USU sebagai lokasi pengabdian akan memberikan dampak yang lebih luas lagi bagi peran Universitas Sumatra Utara sebagai pembawa perubahan utamanya menyangkut keberlangsungan kesehatan di tengahtengah masyarakat di Sumatera Utara.

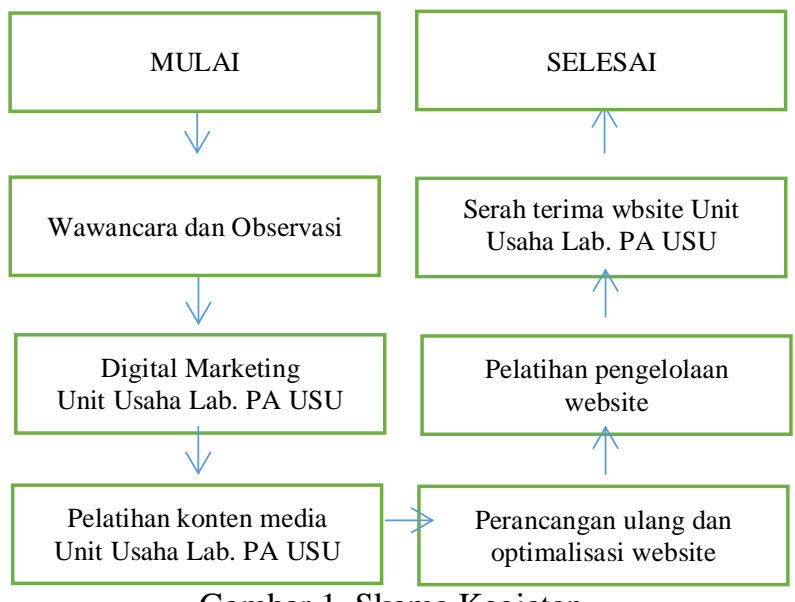

Gambar 1. Skema Kegiatan

Pada gambar 1 di atas, skema kegiatan yang dilaksanakan selama pengabdian dengan memberikan pelatihan dan pendampingan kewirausahaan (seperti teknik digital marketing dan perencanaan pembuatan konten media) serta perancangan ulang website sebagai alat dalam digital marketing.

\section{HASIL DAN PEMBAHASAN}

Media untuk laporan hasil pemeriksaan Patologi Anatomik secara digital berupa kegiatan yang meliputi:

a. Dalam rangka meningkatkan sistem informasi berbasis web laboratorium patologi anatomik. Tim pengabdian telah melakukan pembuatan website multi fungsi, dimana pelaporan hasil pemeriksaan patologi anatomik dapat dilakukan secara online. Selain itu dengan website ini juga dapat menjadi wadah untuk berkonsultasi antara klinisi maupun dengan sesama ahli patologi. 

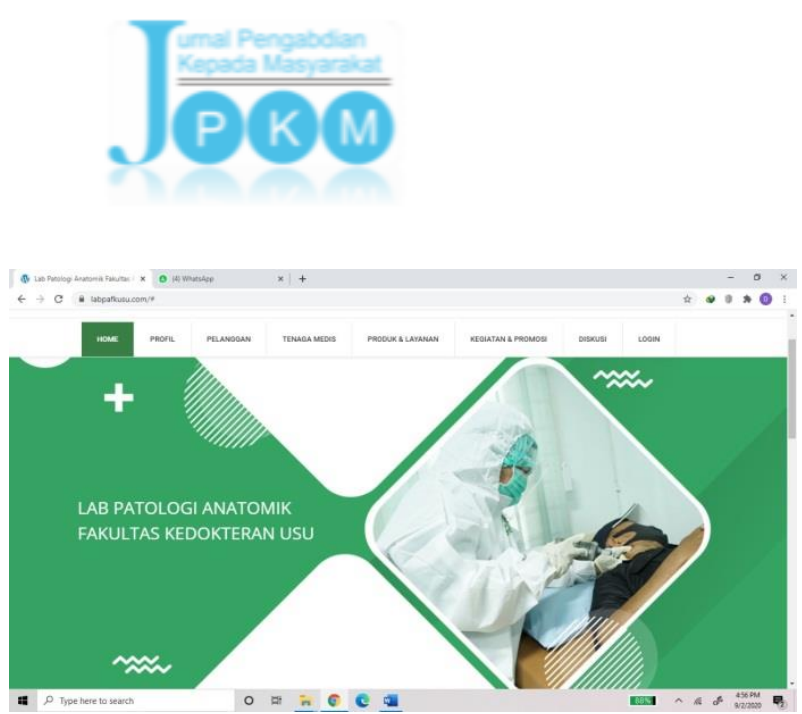

Gambar 2. Tampilan website Lab. PA FK USU

b. Tim pengabdian telah meningkatkan teknik dokumentasi gambar makroskopis dan mikroskopis dengan pengadaan kamera mirorrless. Melalui kamera tersebut diharapkan kualitas gambar akan meningkat, dan dapat disimpan di server laboratorium patologi anatomik FK USU.
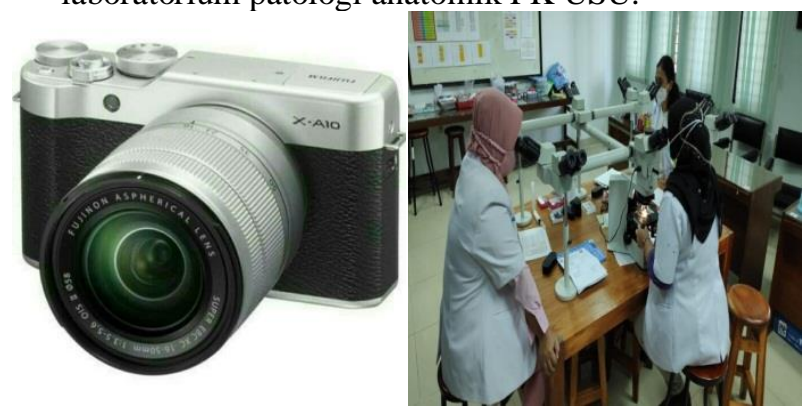

Gambar 3. Kamera yang digunakan untuk dokumentasi mikroskopik

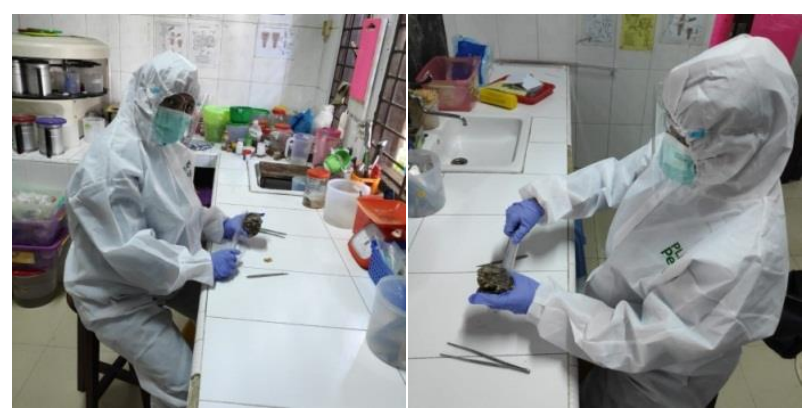

Gambar 4. Dokumentasi kegiatan potong makros

c. Aplikasi zoom sangat berperan penting terutama pada saat ini sebagai langkah pembatasan jarak dan ruang untuk menghadapi pandemi covid 19. Tim pengabdian akan memanfaatkan aplikasi ini sebagai media komunikasi dan pemasaran lab PA secara virtual, setidaknya dalam waktu setahun diharapkan lab PA FK USU akan menjadi pusat rujukan pendidikan dan pelayanan pemeriksaan patologi anatomik.

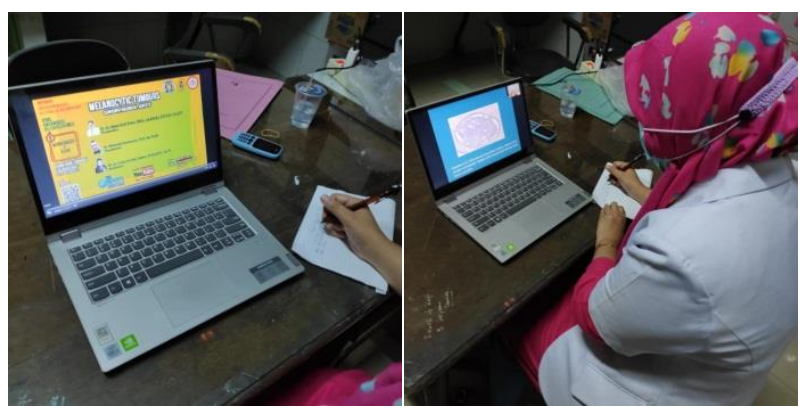

Gambar 5. Kegiatan webinar dan pemeriksaan patologi anatomik menggunakan aplikasi zoom

\section{KESIMPULAN}

Dengan adanya pengembangan teknologi sistem informasi berbasis web, pelaporan hasil pemeriksaan patologi anatomik dalam keadaan pandemi covid 19 akan sangat efektif dan efisien. Terjalinnya komunikasi yang lebih baik dari klinisi dan ahli patologi, sehingga meningkatkan akurasi diagnostik pemeriksaan patologi anatomik.

\section{UCAPAN TERIMA KASIH}

Ucapan terima kasih ditujukan dan terutama disampaikan kepada LPM USU sebagai penyokong dana sehingga terlaksananya pengabdian ini.

\section{DAFTAR PUSTAKA}

Retno Widyastuti, (2013). Pendahuluan Patologi anatomik.

https://www.scribd.com/doc/176610743/Pendahu luan-Patologi-Anatomi-docx\#download.

Sutjahjo, (2007). Ilmu Patologi anatomik Kurang Diminati.

http://www.ui.ac.id/download/kliping/200407/Il mu_Patologi_Anatomi_Kurang_Diminati.pdf.

Riana D, Sanjaya R, Kalsoem O, (2018). Sistem Informasi Manajemen Laboratorium Patologi anatomik Menggunakan Model MVC Berbasis Laravel Framework. http://jurnal.atmaluhur.ac.id/index.php/knsi2018/ article/viewFile/365/290.

Indrayani RS. Laporan Laboratorium Patologi anatomik. https://www.academia.edu/35361459/laporan_lab oratorium_patologi_anatomi.docx.

RSUP Wahidin. Laboratorium Patologi anatomik. http://www.rsupwahidin.com/rujukan/rujukan.ph $\mathrm{p} ? \mathrm{i}=11$.

RSUD MUNTILAN KABUPATEN MAGELANG, 2018. STANDAR PELAYANAN INSTALASI LABORATORIUM PATOLOGI ANATOMIK. http://rsud.magelangkab.go.id/download/file/8.\% 20Standar\%20Pelayanan\%20\%20Instalasi\%20La boratorium\%20Patologi\%20Anatomi.pdf. 
RSUD Pemerintah Kabupaten Sidoarjo. Pelayanan Laboratorium Patologi anatomik. https://sipp.menpan.go.id/pelayanan-publik/jawatimur/kabupaten-sidoarjo/pelayanan-

laboratorium-patologi-anatomi.
Delyuzar, (2012). Patologi anatomik FK USU. https://patologifkusu.wordpress.com/author/drdel yuzar/page/2/.. 